\title{
Changes in Protein Synthesis Accompanying Long-Term Potentiation in the Dentate Gyrus in vivo
}

\author{
M. S. Fazeli, ${ }^{1}$ J. Corbet, ${ }^{2}$, M. J. Dunn, ${ }^{2}$, A. C. Dolphin, ${ }^{1}$ and T. V. P. Bliss ${ }^{3}$ \\ 'Department of Pharmacology, Royal Free Hospital School of Medicine, London NW3 2PF, 'Department of Cardiothoracic \\ Surgery, National Heart and Lung Institute, London SW3 6LY, and 'Division of Neurophysiology and Neuropharmacology, \\ National Institute for Medical Research, London NW7 1AA, United Kingdom
}

The possibility that the induction of long-term potentiation (LTP) is followed by changes in protein synthesis has been examined using high-resolution two-dimensional gel electrophoresis. ${ }^{35}$ S-methionine, infused into the third ventricle of anesthetized rats, was used to label hippocampal proteins. LTP was induced unilaterally in the dentate gyrus by tetanic stimulation of the perforant path, and followed either for $1 \mathrm{hr}$ or for $3 \mathrm{hr}$. Two-dimensional gel autoradiographs were quantitatlvely analyzed using the PDQuest system (Protein Databases Inc.). One hour after the unilateral induction of LTP, only one protein spot was found to be statistically different in intensity from corresponding spots in the contralateral control side. Three hours after LTP, however, 11 spots were found to have altered densities. Examination of basic proteins using the nonequilibrium $\mathrm{pH}$ gel electrophoresis system revealed changes in three proteins in the $3 \mathbf{~ h r}$ group. Reductions as well as increases in spot intensities were observed. The results indicate that LTP is associated with a complex pattern of changes in protein synthesis.

[Key words: long-term potentiation, protein synthesis, twodimensional PAGE, quantitative image analysis, synaptic plasticity, learning and memory]

Synaptic plasticity of the form exemplified by long-term potentiation (LTP) (Bliss and Lomo, 1973) is a plausible mechanism for the neural substrate of learning and memory processes. LTP has been extensively studied in the mammalian hippocampal formation, where it can be induced in all the fast excitatory pathways.

Distinct temporal mechanisms appear to be involved in the expression of LTP, and this has led to the notion of several phases of the potentiation process (see review by Bliss and Lynch, 1988). The induction of LTP, except in the mossy fiber-CA3 synapses, involves the activation of postsynaptically located NMDA receptors (Collingridge et al., 1983; Gustafsson and Wigström, 1988). The subsequent rise in postsynaptic calcium concentration is believed to activate a number of kinases and other enzymes (Linden and Routtenberg, 1989; Malinow et al., 1989). Increased transmitter release (Bliss et al., 1986) and phosphorylation of presynaptic proteins such as GAP-43/F1/B50

\footnotetext{
Received June 3, 1992; revised Sept. 18, 1992; accepted Sept. 22, 1992.

We are indebted to the Nuffield Foundation and the Physiological Society for travel grants to M.S.F. This work was supported by the Wellcome trust.

Correspondence should be addressed to M. S. Fazeli, Department of Experimental Pathology, UMDS, Guy's Hospital, London SE1 9RT, UK.

Copyright (C) 1993 Society for Neuroscience $0270-6474 / 93 / 131346-08 \$ 05.00 / 0$
}

(Routtenberg, 1986; DeGraan et al., 1990) appear to be involved in the maintenance of LTP, possibly accompanied by changes in postsynaptic kinase activity and receptor sensitivity (Davies et al., 1989).

Although posttranslational modifications may sustain LTP over the initial few hours, it is doubtful whether such changes can mediate the more persistent phase(s) of LTP lasting for several days. Learning and memory, as well as the late phase of LTP, have been shown to be susceptible to protein synthesis inhibitors (Squire and Barondes, 1972; Krug et al., 1984). In an in vivo study, Otani et al. (1989) found that if anisomycin, a potent translational inhibitor, was present during the period of high-frequency stimulation and for $15 \mathrm{~min}$ thereafter, EPSP potentiation returned to baseline within $3 \mathrm{hr}$. Transcriptional inhibitors, however, were without effect, suggesting that mRNA encoding for the relevant proteins was present before the tetanus. In freely moving rats, Krug et al. (1984) reported that anisomycin, applied prior to the induction of LTP, blocked all components of LTP lasting more than $3 \mathrm{hr}$. In another study, the induction as well as the maintenance of LTP in the CA1 area of hippocampal slices was blocked by emetine, but not by anisomycin (Stanton and Sarvey, 1984). These results, while not wholly consistent, indicate that the long-term maintenance of LTP requires the synthesis of proteins, at least at the time of induction. This conclusion is supported by reports of changes in gene expression following high-frequency activation of the perforant path (Morris et al., 1988), and by a number of studies indicating changes in immediate early gene expression in LTP (Cole et al., 1989; Jeffery et al., 1990; Wisden et al., 1990; Nikolaev et al., 1991; but see also Schreiber et al., 1991).

In the experiments reported here, we have taken a more direct approach to the examination of changes in protein synthesis associated with LTP. For this purpose we have used high-resolution two-dimensional protein electrophoresis, to separate proteins labeled in vivo with ${ }^{35} \mathrm{~S}$-methionine, 1 or $3 \mathrm{hr}$ after the induction of LTP. This method has been successfully applied to the analysis of protein changes in other systems (Castellucci et al., 1988; Noel et al., 1991).

\section{Materials and Methods}

Electrophysiology. Male Wistar rats were anesthetized with urethane $(2 \mathrm{~g} / \mathrm{kg}$, i.p.). Following placement in a stereotaxic frame, the dorsal skull between bregma and lambda was removed and the brain surface exposed. Bipolar concentric stimulating electrodes were positioned bilaterally to activate the perforant path running in the angular bundle (4.5 $\mathrm{mm}$ lateral to lambda). Glass recording electrodes, filled with $2 \mathrm{M}$ sodium acetate, were inserted bilaterally into the cell body layer of the dentate gyrus ( $4.1 \mathrm{~mm}$ caudal to bregma, $2.8 \mathrm{~mm}$ lateral to midline). 


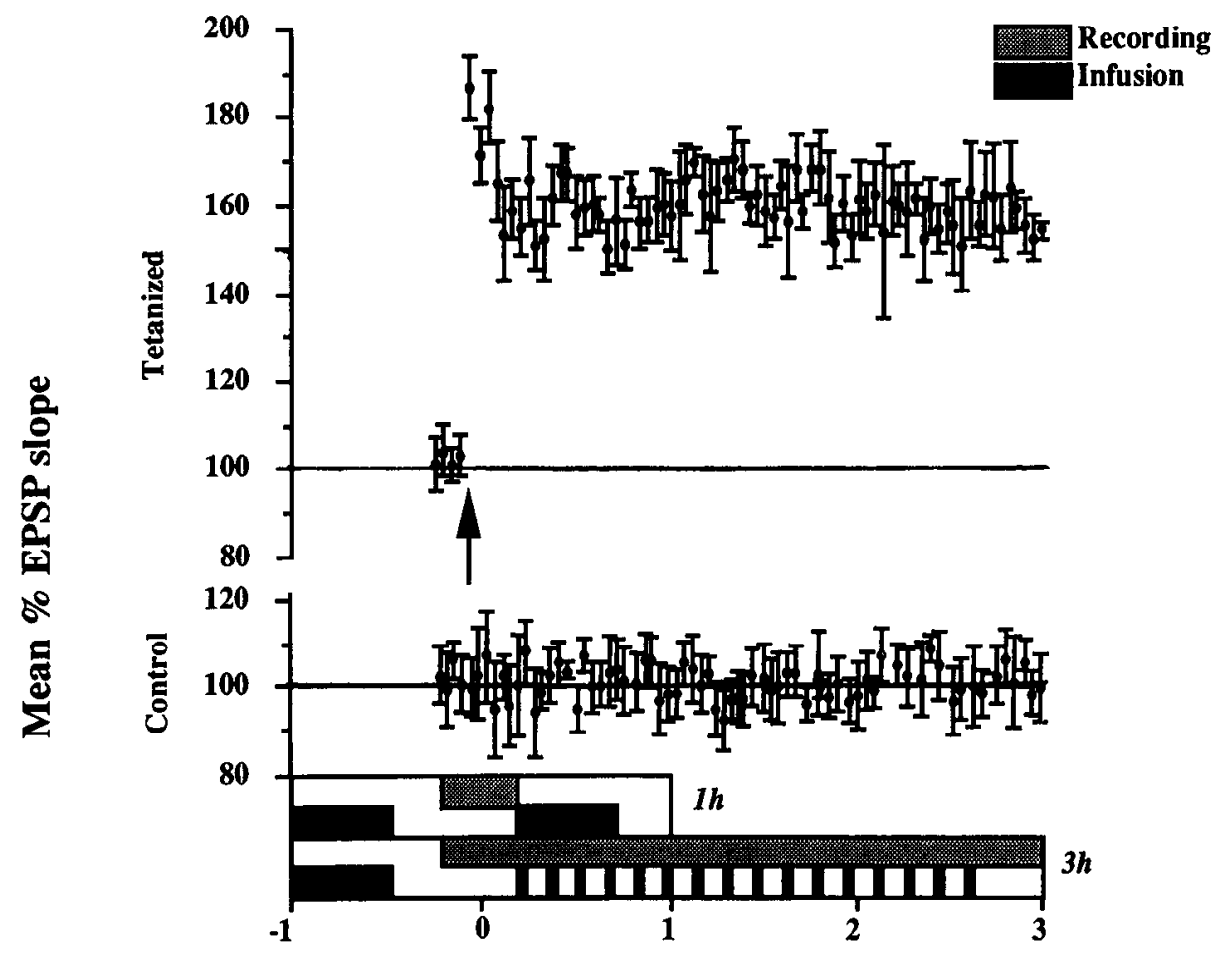

Time (hours)
Figure 1. Induction of LTP in $3 \mathrm{hr}$ experiments represented as the mean increase in the initial slope of the EPSP. Stimulating and recording electrodes were placed bilaterally in the angular bundle and in the cell body layer of the dorsal dentate gyrus, respectively. Stimulation intensity was adjusted to yicld a population spike height of approximately $0.5 \mathrm{mV}$. Evoked potentials were recorded every $30 \mathrm{sec}$. Three episodes of high-frequency stimulation at $250 \mathrm{~Hz}$ for $200 \mathrm{msec}$ were applied $1 \mathrm{hr}$ after the beginning of each experiment $(t=0$, arrrow). Each point on the graph is the average of five potentials $(2.5 \mathrm{~min})$ expressed as the percentage of the mean of those recorded during the $10 \mathrm{~min}$. period prior to induction of LTP. The abscissa bears a schematic representation of the infusion and recording protocols in both $1 \mathrm{hr}(t o p)$ and $3 \mathrm{hr}$ (bottom) experiments.
Following optimization of electrode positions, the stimulus strength was adjusted to give a population spike height of approximately $0.5 \mathrm{mV}$. Test stimuli were delivered at $30 \mathrm{sec}$ intervals $(0.033 \mathrm{~Hz})$, unless otherwise stated. Temperature was constantly monitored via an anal thermometer, and a heating lamp adjusted as required to maintain temperature at $36-37^{\circ} \mathrm{C}$.

${ }^{35} S$-methionine infusion. The coordinates of the recording electrodes were noted and the electrodes were then temporarily removed to allow free access for the cannula and to prevent potential damage to the hippocampus that might otherwise have been caused by movement of the electrodes during infusion. A cannula $(0.5 \mathrm{~mm} \mathrm{o.d}$.) was inserted into the third ventricle ( $2.5 \mathrm{~mm}$ caudal to bregma and $4 \mathrm{~mm}$ deep, at midline). Infusion of ${ }^{35} \mathrm{~S}$-methionine ( $>1000 \mathrm{Ci} / \mathrm{mmol}$; Amersham) was immediately begun using a peristaltic pump, and experiments were continued for either $2 \mathrm{hr}$ or $4 \mathrm{hr}$ according to the following protocol (indicated schematically in Fig. 1). Over the succeeding $30 \mathrm{~min}, 15 \mu \mathrm{l}$ $(250 \mu \mathrm{Ci})$ of label was infused. Fifteen minutes after the end of this infusion period, the recording electrodes were reintroduced into the dentate gyrus at the previously noted positions, and recording commenced. Following $10 \mathrm{~min}$ of basal recording, three high-frequency trains at $250 \mathrm{~Hz}$, each of $200 \mathrm{msec}$ duration, were unilaterally applied at $30 \mathrm{sec}$ intervals. In experiments where LTP was followed for $1 \mathrm{hr}$, recording was continued for a further $10 \mathrm{~min}$, at which time the recording electrodes were again removed. A further $15 \mu \mathrm{l}$ of ${ }^{35} \mathrm{~S}$-methionine was then infused over the next $30 \mathrm{~min}$, to give a total of $500 \mu \mathrm{Ci}$. Twenty minutes after the final infusion period, animals were killed by decapitation. In another set of experiments, LTP was followed for $3 \mathrm{hr}$. In this case it was necessary to spread the infusion of ${ }^{35} \mathrm{~S}$-methionine over the entire time course of the experiment to ensure the presence of unincorporated label at all times. In addition to the $15 \mu \mathrm{l}$ of label administered before high-frequency stimulation (see above), $1 \mu$ l of label was infused over a period of approximately $1 \mathrm{~min}$, beginning $10 \mathrm{~min}$ after the induction of LTP and every $10 \mathrm{~min}$ thereafter (Fig. 1). In these experiments, since the volumes infused at each time point were small, the recording electrodes remained in the hippocampus, thus allowing continuous recording. In all experiments, the contralateral side received the same number of stimuli as the potentiated side. Thus, in $1 \mathrm{hr}$ experiments, after the induction of LTP, the control side was stimulated at $0.05 \mathrm{~Hz}$. In $3 \mathrm{hr}$ experiments, the control side was stimulated at 0.05 $\mathrm{Hz}$ for the first hour after LTP and then at $0.033 \mathrm{~Hz}$ for the remainder of the experiment. At each time point, two separate series of experiments were performed in order to confirm that changes seen in the first series were reproducible ( $n=9$ and 4 for the first and second series of $1 \mathrm{hr}$ experiments, and $n=7$ and 4 for the two series of $3 \mathrm{hr}$ experiments). Sham experiments ( $n=5$ for both time points) were performed exactly as above, except that the high-frequency stimulation was omitted.

Sample preparation. The brain was placed onto ice-cold phosphatebuffered saline (PBS)-impregnated filter paper, the hippocampus was removed, and the dentate gyrus separated. The dorsal half of both dentate gyri was removed into lysis buffer (O'Farrell, 1975), at $10 \mathrm{mg} / 300$ $\mu \mathrm{l}$ (wet weight of tissue). Following homogenization using a Dounce (glass-glass) homogenizer and centrifugation at $12000 \times g$, three $5 \mu \mathrm{l}$ aliquots were spotted onto Whattman 1 Char filter paper squares $(2$ $\mathrm{cm}^{2}$ ). The amount of radioactivity incorporated into trichloroacetic acid (TCA)-precipitable protein was then estimated using liquid scintillation counting. The remaining sample was frozen at $-70^{\circ} \mathrm{C}$.

Isoelectric focusing and nonequilibrium $\mathrm{pH}$ gradient electrophoresis. A solution of $9 \mathrm{M}$ urea, 4\% acrylamide (BDH), 2\% NP-40, and 3\% ampholines $(2.5 \% \mathrm{pH} \mathrm{5-7}$ and $0.5 \% \mathrm{pH} \mathrm{3-10)}$ was prepared using ultrapure degassed water. To make nonequilibrium gels, $2 \%$ ampholines (1\% pH 7-9 and $1 \% \mathrm{pH} 8-9.5)$ were used instead. Following addition of cross-linker (TEMED, Sigma) and catalyst (ammonium persulfate; $\mathrm{BDH}$ ), gels were poured to a height of $15 \mathrm{~cm}$ (glass tubes, $2 \mathrm{~mm}$ i.d.). Following polymerization, up to $20 \mu \mathrm{l}$ of sample, containing the same amount of radioactivity (approximately 300,000 dpm for each sample), was loaded onto the gels. For nonequilibrium $\mathrm{pH}$ gradient electrophoresis (NEpHGE), the samples were overlaid with $8 \mathrm{M}$ urea containing $1 \%$ ampholines $(0.8 \% \mathrm{pH} 5-7$ and $0.2 \% \mathrm{pH} 3-10)$. Isoelectric focusing (IEF) gels were run for a total of $9000 \mathrm{~V} \cdot \mathrm{hr}$, and NEpHGE gels, for $2000 \mathrm{~V} \cdot \mathrm{hr}$. $\mathrm{pH}$ gradients were estimated by running a gel loaded with $20 \mu$ of sample containing IEF standards (Bio-Rad).

At the end of each run, gels were removed from their tubes and immediately frozen and stored at $-70^{\circ} \mathrm{C}$. Gels were kept for up to 1 month prior to electrophoresis on the second dimension.

Second-dimension slab gel electrophoresis. Linear gradient sodium dodecylsulfate (SDS; BDH) gels of 7.5-15\% acrylamide concentration (1.5 mm thick) were used for separation in the second dimension, according to Laemmli (1970). Gels were cast to a height of $20 \mathrm{~cm}$ with a $2 \mathrm{~cm} \mathrm{(3 \% )} \mathrm{stacking} \mathrm{gel.} \mathrm{Rod} \mathrm{gels} \mathrm{were} \mathrm{thawed} \mathrm{and} \mathrm{placed} \mathrm{in} \mathrm{equilibration}$ buffer, consisting of $0.06 \mathrm{M}$ Tris-HCl (pH 6.8; Sigma), 2\% SDS, 5\% $\beta$-mercaptoethanol (BDH), and $10 \%$ glycerol (BDH), for $1-2 \mathrm{~min}$. These were then applied to the top of the stacking gel and overlaid with $1 \%$ molten agarose (Pharmacia) in the above buffer, containing a trace amount of bromo-phenol blue as tracking dye. Electrophoresis was carried out 
Figure 2. Computer-assisted quantitative analysis of two-dimensional gel autoradiographs. Autoradiographs $[A$; IEF, right to left ( $\mathrm{pH} 7.5-4)$; SDS PAGE, top to bottom (MW 300-10 kDa)] were scanned using a Molecular Dynamics laser scanner set at an optical density range of $0-3.5$. Spot detection and further computer analysis were achieved using the PDQUEST software of Protein Databases Inc. Following background subtraction and spot detection $(B)$, the image was edited to remove spurious streaks and spots $(C)$.

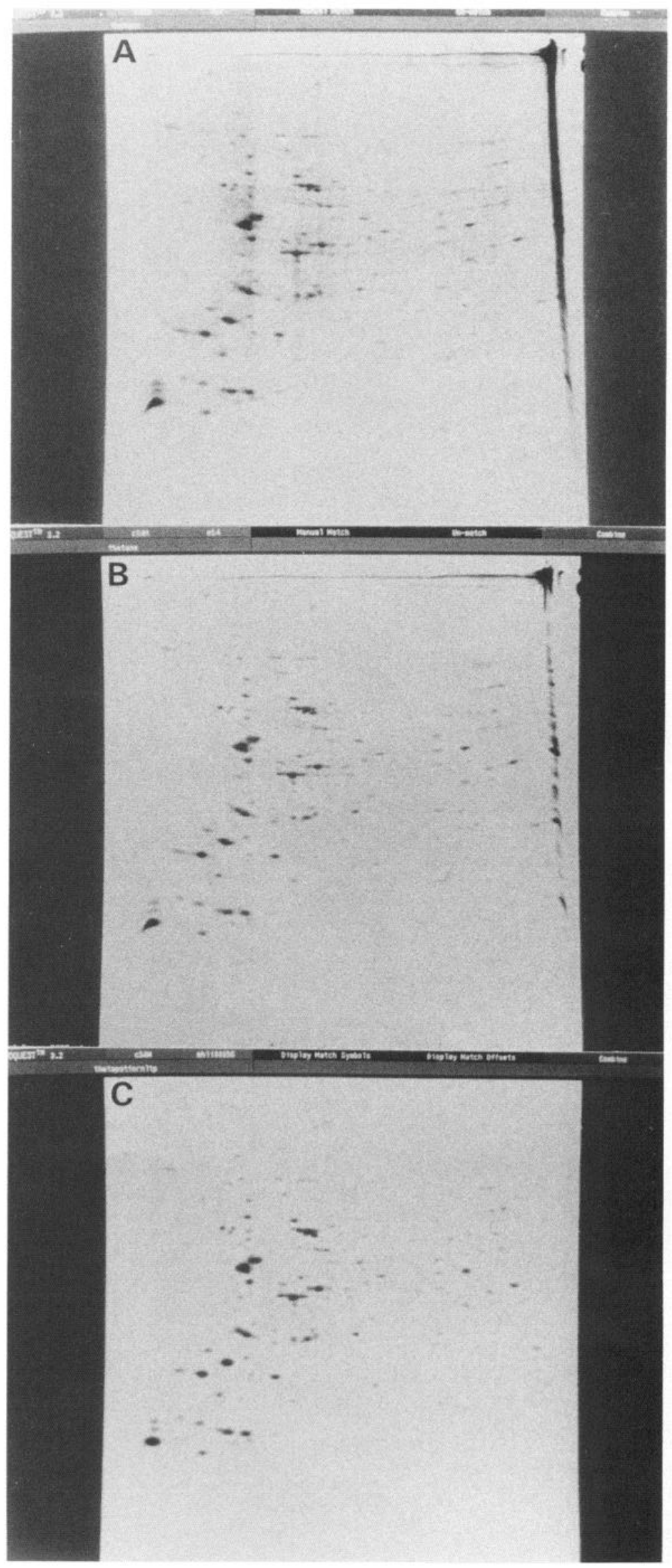




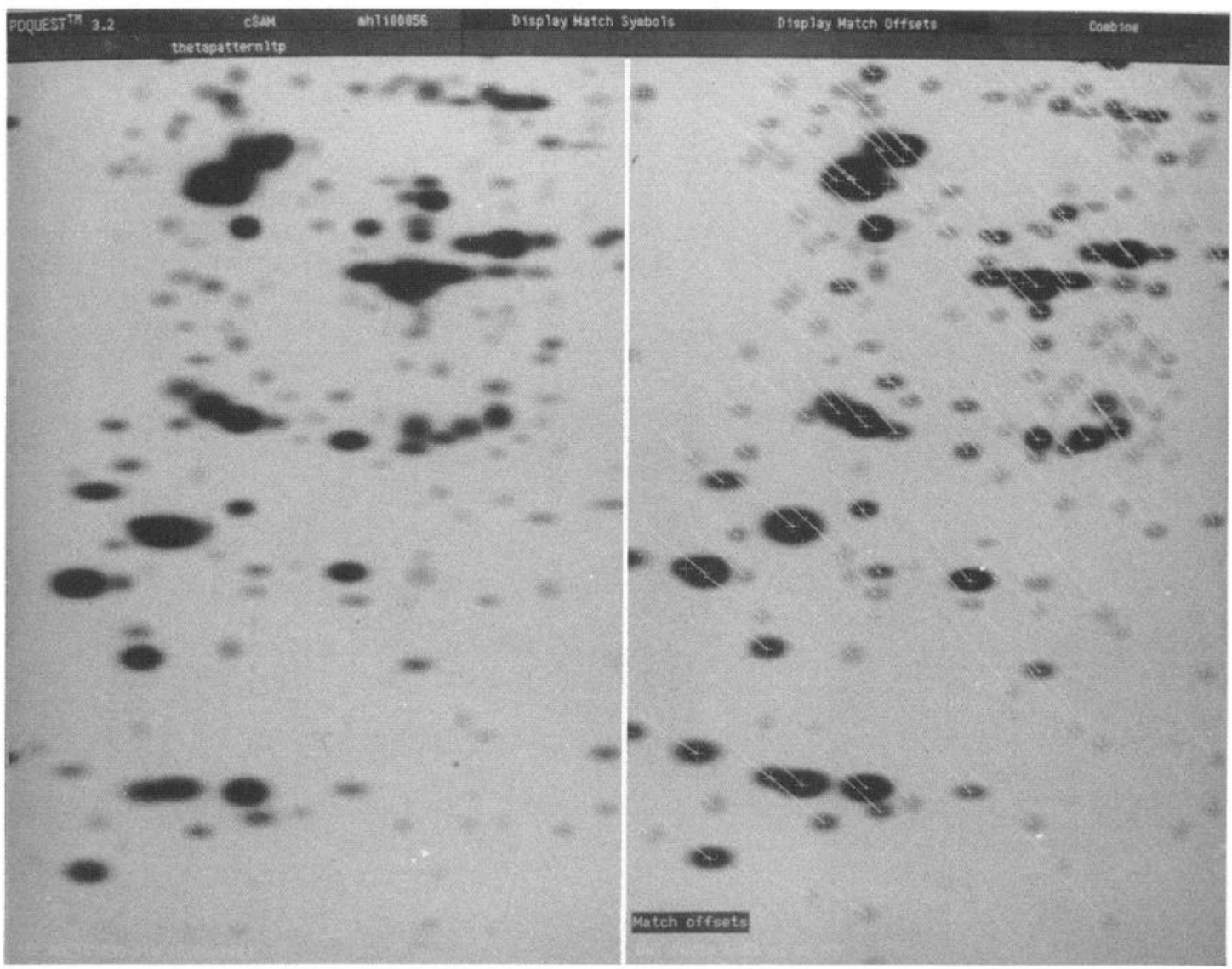

Figure 3. All images were matched to the standard gel image (left). Landmarks (spots that were consistently seen by eye to be present on all gels) were designated on the standard image. These were used by the computer to achieve automatic matching of all images to the standard. By placing the standard side by side with each image, the quality of every match could be checked. The "zoomed in" gel image on the right shows the "match offsets." These are vectors drawn by the computer that assist in identifying mismatches, which are subsequently rectified manually by reference to the "zoomed in" standard image on the left.

overnight at $15 \mathrm{~mA}$ per gel. At the end of each run, gels were removed and stained with $0.25 \%(\mathrm{w} / \mathrm{v})$ Coomassie blue in $50 \%$ methanol, $10 \%$ acetic acid (BDH). Following destaining, the gels were dried and multiple exposures were obtained using autoradiography film $(\beta$ max-Hyperfilm, Amersham) at $-70^{\circ} \mathrm{C}$.

Quantitative image analysis. Analysis of changes in protein spot density on autoradiographs was carried out using the PDQUEST system (Protein Databases Inc.; Garrels, 1989). Gels were scanned using a Molecular Dynamics laser densitometer $(300 \mathrm{H})$ attached to a Sun Sparc station (gel scan, Fig. 2A). Following background subtraction, editing, and spot fitting (gel image and spots, Fig. $2 B, C$, respectively), protein spots were manually edited for spurious spot detection or missed spots. The gel with the greatest number of spots was chosen as a standard image, to which all other gels were matched. Spots were assigned standard spot numbers, for identification and databasing, using a rectilinear coordinate system superimposed on the standard gel image. Matching was performed by manually selecting a number of landmark spots, over the entire gel area (about 20), whose positions on all gels were readily recognizable. The computer automatically matched other spots with reference to the landmarks provided. Because of nonlinear changes in spot positions on gels within the same experimental series, mismatches and nonmatches were occasionally encountered. For this reason, all matches were thoroughly investigated, using the available editing functions (Fig. 3). The data were then arranged into experimental (LTP) and control groups, and statistical comparisons of spot densities [expressed as a proportion (ppm) of total spot density] in the two groups were performed using Student's $t$ test and Mann-Whitney $U$ test, and only differences with a probability of $<0.05$ in both tests were designated as significant. For the purposes of this study, only spots that appeared on all gels were considered for analysis, since the presence of a spot in some gels and its absence in others cannot be unequivocally attributed to de novo changes. (In no case was a spot present in every control gel and absent from every LTP gel, or vice versa.) Significant spots were then reassessed in terms of match quality and other possible errors. Saturated spots (an average of four or five per gel) were not included in the analysis and were omitted from the total spot density in the calculations of ppm values.

\section{Results}

\section{LTP induction and ${ }^{35} S$-methionine labeling}

LTP was invariably induced following high-frequency stimulation of the perforant path. Figure 1 shows the mean change in the initial slope of the EPSP, depicted as percentages of the average EPSP slope $5 \mathrm{~min}$ prior to high-frequency stimulation, for control and potentiated sides in all $3 \mathrm{hr}$ experiments.

The third ventricle was chosen for ${ }^{35} \mathrm{~S}$-methionine infusion since it is bounded in part by the dorsal blade of the dentate gyrus, hence optimizing delivery of label bilaterally to the areas of interest. The disadvantage of the midline approach was the danger of damage to the blood vessel plexus of the sagittal sinus, and about $20 \%$ of experiments had to be abandoned because of uncontrollable bleeding.

The amount of radioactivity incorporated into TCA-precipitable protein in $3 \mathrm{hr}$ experiments was higher than in $1 \mathrm{hr}$ experiments. Thus, the left and right dentate gyri (irrespective of potentiation) in $1 \mathrm{hr}$ experiments incorporated counts of 68,071 $\pm 15,521$ and $57,893 \pm 11,786 \mathrm{dpm}$, respectively (mean \pm SEM, in $5 \mu$ l aliquots), while the corresponding values in $3 \mathrm{hr}$ experiments were $90,248 \pm 17,258$ and 107,644 $\pm 21,936 \mathrm{dpm}$, 


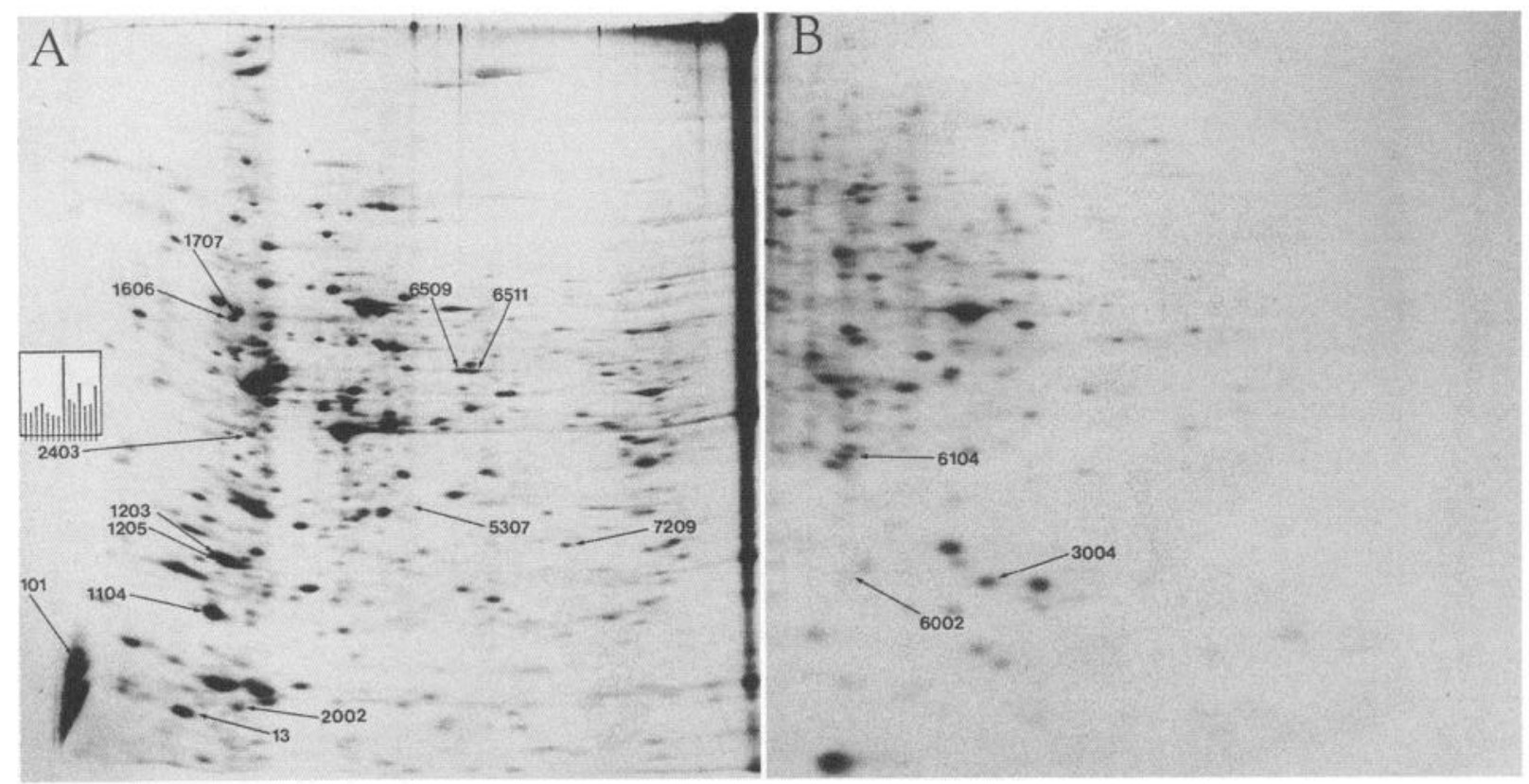

Figure 4. Quantitative computer analysis reveals changes in the intensities of several spots following the induction of LTP. An IEF autoradiograph is presented in $A$, marked with the numbers of all spots whose densities were found to be significantly altered by the induction of LTP in the first series of experiments (both $1 \mathrm{hr}$ and $3 \mathrm{hr}$ ). Spots 13 and 1104 were found to be reduced $1 \mathrm{hr}$ following the induction of LTP (first series, $n=9$ ). All other marked spots were found to be significantly altered $3 \mathrm{hr}$ after the induction of LTP (first series, $n=7$ ). The inset shows a "spot graph" produced by PDQUEST. This is a histogram of the densities (ppm; see text) of spot 2403 in the LTP group (seven histobars on the left) and the control group (seven histobars on the right), in the $3 \mathrm{hr}$ experiments (first series). B shows a typical NEpHGE autoradiograph (right to left, pH 7.5-11.5) marked with the numbers of the spots found to be significantly altered $3 \mathrm{hr}$ after LTP $(n=6)$. No differences were detected $1 \mathrm{hr}$ after LTP.

respectively. In the normalization process, PDQUEST calculates the "load," the value of which is related to the total spot density of the autoradiograph. The total calculated loads for LTP and control groups were, respectively, 30,049 \pm 2653 and 33,256 \pm 2938 in $1 \mathrm{hr}$ experiments and 45,414 \pm 8268 and 43,984 \pm 9791 in $3 \mathrm{hr}$ experiments. It is clear that the degree of incorporation of label is directly reflected in the total spot density of autoradiographs. The average number of spots on autoradiographs from $1 \mathrm{hr}$ and $3 \mathrm{hr}$ experiments was the same (approximately 700). This indicates that the main difference in the incorporation of label between $1 \mathrm{hr}$ and $3 \mathrm{hr}$ experiments is in the amount incorporated into the same proteins rather than an increase in the number of radiolabeled protein species (see below).

\section{IEF and nonequilibrium $\mathrm{pH}$ two-dimensional $P A G E$ reveal several quantitative changes}

Quantitative image analysis was used to compare the spot densities of the LTP and control groups. For illustration, Figure $4 \mathrm{~A}$ shows an autoradiograph of an IEF gel and Figure $4 B$ depicts an NEpHGE autoradiograph of the same sample, taken from one of the seven $3 \mathrm{hr}$ experiments, first series. Approximately 700 spots were detected on a typical IEF gel and 250 on a nonequilibrium $\mathrm{pH}$ gel. Each autoradiograph is marked with the identification numbers of the spots that were found to be significantly altered as a result of the induction of LTP in both $1 \mathrm{hr}$ and/or $3 \mathrm{hr}$ experiments in the first series. The inset in Figure $4 A$ is a histogram ("spot graph"), generated by PDQUEST, of the ppm values for spot number 2403 in the autoradiographs prepared from the potentiated sides (seven histobars on left), followed by the consistently higher values found in corresponding autoradiographs from the control sides (seven histobars on right).
In the $1 \mathrm{hr}$ experiment (first series, $n=9$ ), only two spots whose densities (ppm) differed significantly in the LTP and control sides were detected. These were low-molecular-weight acidic proteins 1104 and 13 (Fig. $3 A$ ). Figure 5 shows the region containing spot 1104 (arrow) in the $1 \mathrm{hr}$ experiments from the first series. A reduction in spot density on the potentiated side is apparent in eight of the nine pairs of autoradiographs. Note also that other proteins in the vicinity of this spot did not show any consistent change.

The average ppm of 12 protein spots on IEF autoradiographs was altered $3 \mathrm{hr}$ after the induction of LTP in the first series ( $n$ $=7$ ). These are also marked on Figure $4 A$. Spots that were significantly different in the $3 \mathrm{hr}$ experiments were also present on $1 \mathrm{hr}$ autoradiographs, but with the exception of spot 1104, no significant changes between control and potentiated sides were evident at $1 \mathrm{hr}$. Using the NEpHGE system, which allows the separation of very basic proteins not separable by IEF, significant changes in three spots were observed, only in the $3 \mathrm{hr}$ experiments. These are noted in Figure $4 B$. No changes were seen at $1 \mathrm{hr}$ using this system.

The second series of experiments at each time point was carried out to filter out differences expected from repeated sampling (type I errors). In the repeat series of $1 \mathrm{hr}$ experiments $(n=4)$, only spot 1104 was found to be significantly reduced in the LTP group compared to the control group. In the $3 \mathrm{hr}$ repeat series $(n=4)$, however, 11 of the 12 significant spots showed changes similar to those seen in the first series. Thus, most of the significant differences detected in the first series were replicated in the repeat series. In the sham experiments $(1 \mathrm{hr}$ and $3 \mathrm{hr}$ series, $n=5$ in each case) and in the NEpHGE experiments ( $1 \mathrm{hr}$ series, $n=6)$, no significant differences at all were found. The average coefficient of variation in the ppm of the spots in all experimental series was $20.5 \%( \pm 1.7)$, which is about the same as that 
reported by Garrels (1989), using a different QUEST-based system.

Figure 6 summarizes the changes for each spot that showed significant changes in both the first and repeat series; changes are plotted as the ratio of the average ppm values on the LTP and control sides. For comparison the ppm ratio of each corresponding spot from the sham experiments is also presented. Molecular weight, pI, and a summary of changes for all spots that showed significant changes at either times following the induction of LTP are given in Table 1.

\section{Discussion}

These experiments were intended as an initial exploration of changes in protein synthesis that might occur in response to LTP-inducing stimuli. We have described changes in the normalized spot density of a variety of protein species, whose identities are presently unknown. The stimulating placement that we have used in the angular bundle, and the parameters of the tetanus, should produce maximal LTP in a substantial proportion of perforant path fibers in the dorsal dentate gyrus.

LTP of $1 \mathrm{hr}$ duration was accompanied by significant changes in only one protein (1104), which manifested a modest reduction in synthesis (or an increase in degradation). It is possible, though hardly likely, that at this time point the synthesis of every protein increased, except for 1104 , leading to an apparent reduction in its intensity. After $3 \mathrm{hr}$, however, numerous increases and decreases were observed. A recent report has indicated changes in the synthesis of two polypeptides $30 \mathrm{~min}$ and $3 \mathrm{hr}$ after both low- and high-frequency afferent stimulation of area CA1 in vitro (Venishi et al., 1991). The molecular size and $\mathrm{pI}$ of these proteins do not correspond to any of the ones that we have detected.

It has recently been reported that LTP is associated with a general increase in protein synthesis (Lossner et al., 1990); this would be undetectable using our technique. Because the same amount of radioactivity was loaded onto each gel and ppm values were used in analysis, only changes in the relative distribution of radiolabel among spots could be detected. Although our approach limits the analysis to relative changes in labeling, it was forced on us by the inevitable variations in the degree of labeling of the two hemispheres.

Experiments using the translational blocker anisomycin suggest that inhibition of protein synthesis at the time of the tetanus reduces the duration of LTP to about $3 \mathrm{hr}$ (Otani et al., 1989). When given as little as $15 \mathrm{~min}$ later, however, anisomycin was ineffective, at least for the first $3 \mathrm{hr}$; longer periods were not monitored. Our results, indicating that posttetanic changes in protein synthesis continue for more than $1 \mathrm{hr}$, can be reconciled with these observations if it is assumed that the proteins we have detected are important for the maintenance of LTP lasting for many hours or days.

The changes reported here may be due to changes in mRNA stabilization and/or destabilization, or alterations in gene expression in potentiated cells. Most changes were modest, possibly because they were associated only with granule cells, and not with glial cells or interneurons.

The quantity of many of the proteins is far too low to allow direct sequencing from one gel. By pooling spots from as many as 15 gels, however, we have established that most of the proteins of interest are not directly sequenceable, probably due to $\mathrm{N}$-terminal blockage. Amino acid analysis of peptides generated by limited proteolytic digestion has been successfully used to
LTP
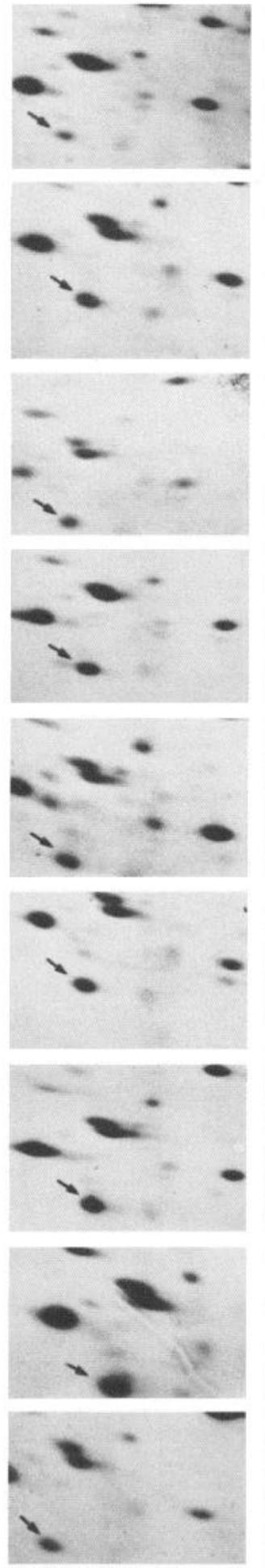

Figure 5. Selected parts of autoradiographs from LTP and control (CTL) $1 \mathrm{hr}$ experiments (first series) showing the position of spot 1104 (arrows; $n=9$ ). The reduction in the density of spot 1104 in the LTP condition can be seen in all but the fourth pair from the top, where there is no difference. This spot was also significantly reduced in the second series and in the $3 \mathrm{hr}$ experiments (see Fig. 6). 
Figure 6. Graphic representation of significant spot ppm changes in $1 \mathrm{hr}$ (solid bars), $3 \mathrm{hr}$ (hatched bars) and sham (open bars) experiments. The mean $( \pm$ SEM) of the ratio of the ppm (calculated by the computer) of each spot in the LTP group compared with the control group is presented. For each spot the ppm ratio from both series at $1 \mathrm{hr}$ $(n=13$, IEF $)$ and $3 \mathrm{hr}(n=11, \mathrm{IEF})$ is plotted. The three bars on the right are ppm ratios of spots found to be significantly altered only $3 \mathrm{hr}$ after LTP in NEpHGE experiments. ${ }^{*}, p \leq 0.05 ;{ }^{* *}$, $p \leq 0.01$; Student's $t$ test and MannWhitney $U$ test.

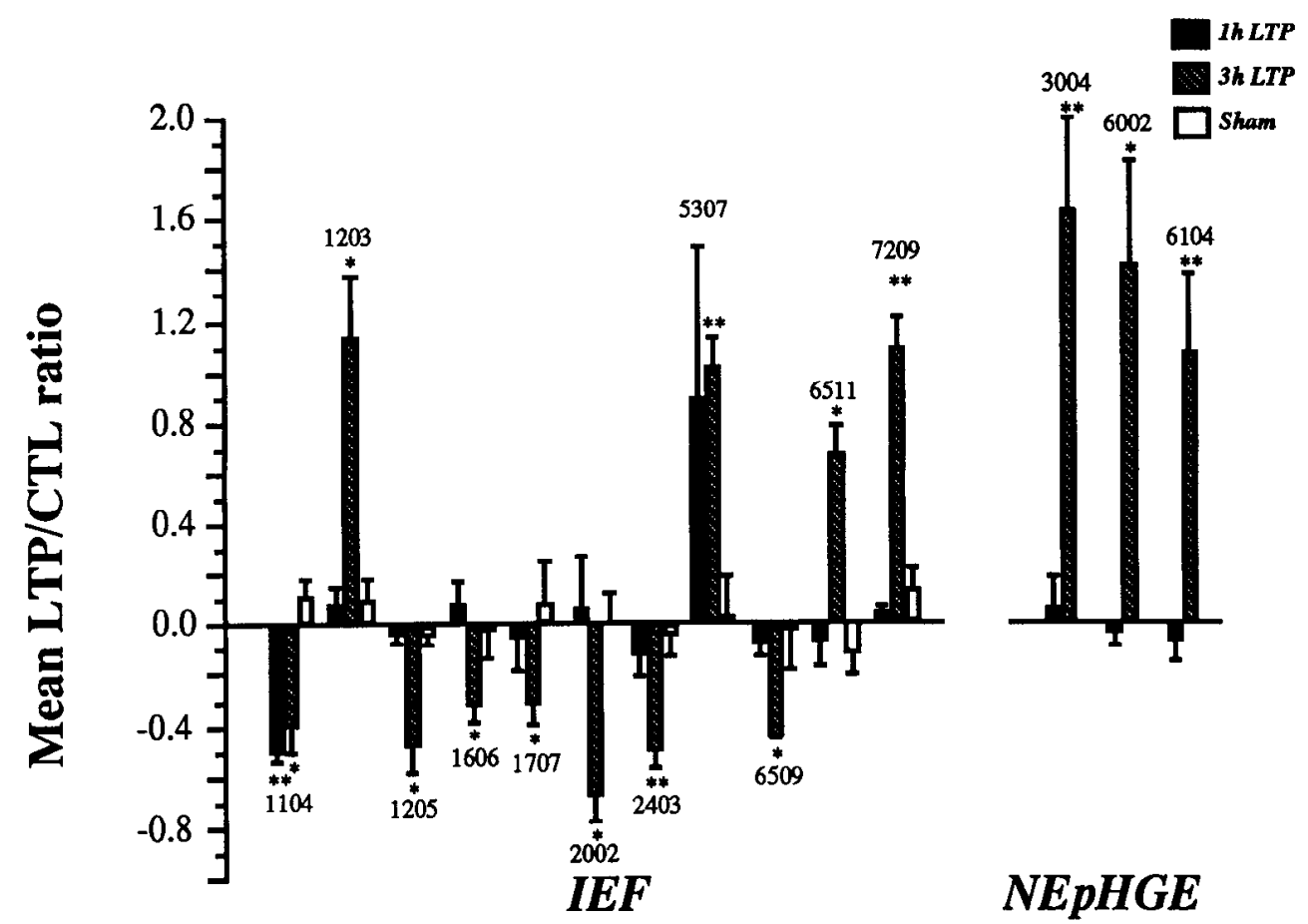

\begin{tabular}{|c|c|c|c|c|c|c|}
\hline \multirow{2}{*}{$\begin{array}{l}\text { Standard } \\
\text { spot } \\
\text { number }\end{array}$} & \multirow[b]{2}{*}{ Mw } & \multirow[b]{2}{*}{$\mathrm{pI}$} & \multicolumn{2}{|c|}{ First series } & \multicolumn{2}{|c|}{ Second series } \\
\hline & & & $\begin{array}{l}1 \mathrm{hr} \\
(n=9)\end{array}$ & $\begin{array}{l}3 \mathrm{hr} \\
(n=7)\end{array}$ & $\begin{array}{l}1 \mathrm{hr} \\
(n=4)\end{array}$ & $\begin{array}{l}3 \mathrm{hr} \\
(n=4)\end{array}$ \\
\hline \multicolumn{7}{|l|}{ IEF } \\
\hline 13 & $<15$ & 5.4 & - & $(-)$ & $(-)$ & $(-)$ \\
\hline 101 & 15 & $<5$ & 0 & - & 0 & 0 \\
\hline 1104 & 25 & 5.6 & -- & - & -- & - \\
\hline 1203 & 26 & 5.6 & 0 & + & 0 & + \\
\hline 1205 & 25 & 5.6 & 0 & - & 0 & - \\
\hline 1606 & 62 & 5.7 & 0 & - & 0 & - \\
\hline 1707 & 63 & 5.7 & 0 & - & 0 & - \\
\hline 2002 & $<15$ & 5.8 & 0 & & 0 & - \\
\hline 2403 & 43 & 5.8 & 0 & -- & 0 & - \\
\hline 5307 & 35 & 6.3 & $(+)$ & ++ & $(+)$ & ++ \\
\hline 6509 & 48 & 6.6 & 0 & - & 0 & - \\
\hline 6511 & 48 & 6.5 & 0 & + & 0 & + \\
\hline 7209 & 31 & 7.1 & 0 & ++ & 0 & ++ \\
\hline \multicolumn{7}{|l|}{ NEpHGE } \\
\hline 3004 & 25 & ND & 0 & ++ & ND & ND \\
\hline 6002 & 25 & ND & 0 & + & ND & ND \\
\hline 6104 & 36 & ND & 0 & ++ & ND & ND \\
\hline
\end{tabular}

The apparent $\mathrm{Mw}(\mathrm{kDa})$ and isoelectric point $(\mathrm{pI})$ of proteins that were found significant in one or both series of experiments are given. The direction of change in the ppm of each spot as a ratio of LTP: control is also presented. A negative indicates a reduction, and a positive, an increase. The number of the signs indicates their degree of significance: $-1+, p \leq 0.05 ;--1++, p \leq 0.01$. Signs in parentheses depict nonsignificant changes, and a zero indicates no change. $\mathrm{ND}$, not determined.

sequence proteins that change following long-term sensitization in Aplysia (Kennedy et al., 1988). The applicability of a similar technique to hippocampal proteins is being investigated.

\section{References}

Bliss TVP, Lømo T (1973) Long-lasting potentiation of synaptic transmission in the dentate area of the anesthetized rabbit following stimulation of the perforant path. J Physiol (Lond) 232:331-356.
Bliss TVP, Lynch MA (1988) Long-term potentiation of synaptic transmission in the hippocampus: properties and mechanisms. In: Neurology and neurobiology, Ser 35, Long-term potentiation: from biophysics to behaviour (Landfield PW, Deadwyler SW, eds), pp 372. New York: Liss.

Bliss TVP, Douglas RM, Errington ML, Lynch MA (1986) Correlation between long-term potentiation and release of endogenous amino acids from dentate gyrus of anaesthetized rats. J Physiol (Lond) 377: $391-408$. 
Castellucci VF, Kennedy TE, Kandel ER, Goelet P (1988) A quantitative analysis of 2-D gels identifies proteins in which labelling is increased following long-term sensitization in Aplysia. Neuron 1:321328.

Cole AJ, Saffen DW, Baraban JM, Worley PF (1989) Rapid increase of an immediate early gene messenger RNA in hippocampal neurones by synaptic NMDA receptor activation. Nature 340:474-476.

Collingridge GL, Kehl SJ, McLennan H (1983) Excitatory synaptic transmission in the Schaffer collateral-commissural pathway of the rat hippocampus. J Physiol (Lond) 334:33-46.

Davies SN, Lester RAJ, Reymann KG, Collingridge GL (1989) Temporally distinct pre- and postsynaptic mechanisms maintain longterm potentiation. Nature 338:500-503.

DeGraan PNE, Schrama LH, Heemskerk FMJ, Dekker LV, Gispen WH (1990) The role of protein kinase C substrate B-50 (GAP-43) in neurotransmitter release and long-term potentiation. $\Lambda \mathrm{d} v \operatorname{Exp} \mathrm{Med}$ Biol 268:347-358.

Garrels JI (1989) The QUEST system for quantitative analysis of twodimensional gels. J Biol Chem 264:5269-5282.

Gustafsson B, Wigström H (1988) Physiological mechanisms underlying long-term potentiation. Trends Neurosci 11:156-162.

Jeffery KJ, Abraham WC, Dragunow M, Mason SE (1990) Induction of Fos-like immunoreactivity and the maintenance of long-term potentiation in the dentate gyrus of unanaesthetized rats. Mol Brain Res 8:267-274.

Kennedy TE, Gawinowicz MA, Barzilai A, Kandel ER, Sweatt JD (1988) Sequencing of proteins from two-dimensional gels by using in situ digestion and transfer of peptides to polyvinylidene difluoride membranes: application to proteins associated with sensitization in Aplysia. Proc Natl Acad Sci USA 85:7008-7012.

Krug M, Lossner B, Ott T (1984) Anisomycin blocks the late phase of long-term potentiation in the dentate gyrus of freely moving rats. Brain Res Bull 13:39-42.

Laemmli UK (1970) Cleavage of structural proteins during the assembly of the head of bacteriophage T4. Nature 227:680-685.

Linden DJ, Routtenberg A (1989) The role of protein kinase C in long-term potentiation: a testable model. Brain Res Rev 14:279-296.

Lossner BB, Schweigert C, Krug M, Matthies HK (1990) Posttetanic long-term potentiation in the dentate gyrus of freely moving rats is accompanied by an increase in protein synthesis. Biomed Biochem Acta 49:385-392.
Malinow R, Schulman H, Tsien RW (1989) Inhibition of postsynaptic PKC or CaMKII blocks induction but not expression of LTP. Science 245:862-866.

Morris BJ, Feasey KJ, Bruggencate GT, Herz A, Holt V (1988) Electrical stimulation in vivo increases the expression of proenkephalin mRNA and decreases the expression of prodynorphin mRNA in rat hippocampal granule cells. Proc Natl Acad Sci USA 85:3226-3230.

Nikolaev E, Tischmeyer W, Krug M, Matthies H, Kaczmarek L (1991) c-fos protooncogene expression in rat hippocampus and entorhinal cortex following tetanic stimulation of the perforant path. Brain Res 560:346-349.

Noel F, Scholz KP, Eskin A, Byrne JH (1991) Common set of proteins in Aplysia sensory neurones affected by an in vitro analogue of longterm sensitization training, 5-HT and cAMP. Brain Res 568:67-75.

O'Farrell PH (1975) High resolution two-dimensional electrophoresis of proteins. J Biol Chem 250:4007-4021.

Otani S, Marshal CJ, Tate WP, Goddard GV, Abraham WC (1989) Maintenance of long-term potentiation in rat dentate gyrus requires protein synthesis but not messenger RNA synthesis immediately posttetanization. Neuroscience 28:519-526.

Routtenberg A (1986) Synaptic plasticity and protein kinase C. Prog Brain Res 69:211-234.

Schreiber SS, Maren S, Tocco G, Shors TJ, Thompson RF (1991) A negative correlation between the induction of long-term potentiation and activation of immediate early genes. Mol Brain Res 11:89-91.

Squire LR, Barondes SH (1972) Variable decay of memory and its recovery in cycloheximide-treated mice. Proc Natl Acad Sci USA 69: 1416-1420.

Stanton PK, Sarvey JM (1984) Blockade of long-term potentiation in rat hippocampal $\mathrm{CAl}$ region by inhibitors of protein synthesis. J Neurosci 4:3080-3088.

Venishi N, Shors TJ, Finch CE, Nichols NR, Thompson RF (1991) Increased synthesis of two polypeptides in area CAl of hippocampus in response to repetitive electrical stimulation. Brain Res 567:248252.

Wisden W, Errington ML, Williams S, Dunnet SB, Waters C, Hitchcock D, Evan G, Bliss TVP, Hunt SP (1990) Differential expression of immediate early genes in the hippocampus and spinal cord. Neuron $4: 603-614$. 